\title{
團結起來，雼執行我們光榮的 歴史任務而雷鬥!
}

社論

中央人民政府政務院在 1 月 28 日舉行的第 204次政務會議中，討論了亚批准了“關於中國科 學院的基本情况和今後工作任䂆的報告”。這是有 關我國科學事業發逃的一件大事。這個報告所分 析的一些問題是目前全國科學工作虽的主要問 题; 報告中所提出的今後中國科學院的工作任狢, 在許多方话, 也是全國科學界的工作任汾。在全國 科學工作者對於國家在過渡時期的總路線和總任 務進行了系統的全面的初步學習以後, 中國科學 院塄個重要報告的發表, 將使蓝大的科學工作者 進一步認識到在過渡㭙期中科學工作的任拐和科 學工作在社會主義建設中的地位。從這裹, 每個人 将更朋確地找到自己具復的努力方向。毫無疑蒌, 道個報告將得到全國科學工作者的熱烈的埦護。

在我國進人計劃經流建没的第二個年頍，如 何發展利學事業的問題, 已經提到國家建設的重 要議事日程上隶了。利䍙的俞展是和偉大的社會 主義建没事業分不開的。在十月革命勝利後不久, 列寧就反覆地指出, 没有現代科學的基礎, 共産 主義不能建設成功。摩史上從來沒有一個階級像 建造着社會主義社會的工人階級违樣重視與關懷 科學事業。蘇聯科學發展的道路, 生動地證明了 只有和工人階級的事業結合在一起, 科學才能得 到解放，科䍙的理想甫能得到霓現，科學的知識 才能真正地成篇改造世界、篇人民謀福利的偉大

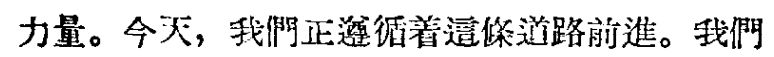
的科學工作現在已經成篇, 將來更要成篇社會主 義建設的一個重要組成部分。在偉大的過渡時期

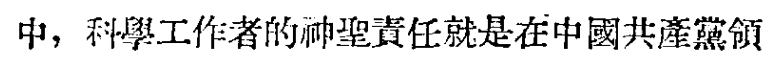

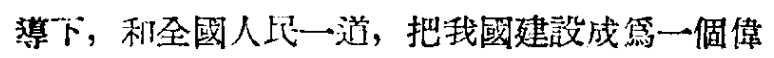

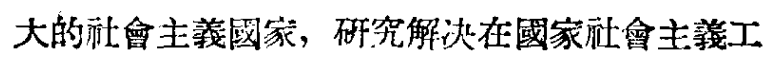
業化和社會主義炂造吅的各项科學問題。在自然
科學方面, 應努力第筫現國家社會主義工業化, 克服我國工業技術落後、䝿源不清、技術幹部 少等困難條件, 第促進慰業合作化、提高農業收 穫量和保護營動人民的健康, 淮行必要的科學研 究工作, 並相應地發展基本理論的研究, 使之成 篇不斷支援國家建設和提高科學水本的有力保

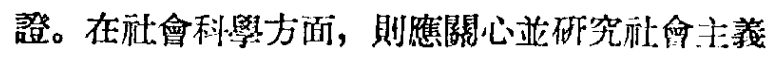

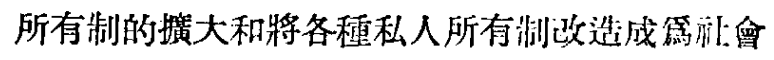

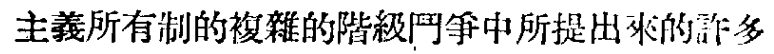
問題, 特别是要從各個方面向全國人民進行施會 主義思想的宣傅和敉育，對資本主菜思想的损簬 和批制。

國家建設對於科學工作的要求是極其士大而而 迫切的, 但我們科學工作的力量却很小。道是山 於舊中國留下來的科學基礎䔦弱, 水平不高, 科 學人員數量很少, 發赈不本衡。任移大, 力量小, 造就是當前科學工作的最突出的矛盾。要解决遭 個矛盾, 最根本的辦法是培食幹部, 發展新生力 量。但科學幹部的生長和科學經驗的皘照都需婆 相當長的時間，而科學幹部的唔養工作和解决目 前迫不及待的國家建設中的科學問題, 都必须依 靠現有的力量。因此怎樣準確地使用這極其有限 的力量, 使它能發生最大的效果, 也就是冯定科學! 事業發鼠的一個最根本的理諭聯系惯際的問題。 在這裹, 我們不能问意那種對建設融會立莪的偉 大事業漠不關心, 孤立地搞磁究工作的保向, 因

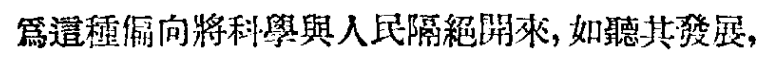
會使科學得不到繁榮與婹展。阔時, 我們也不能同

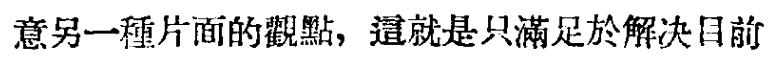
的一些問題, 看不罗在㼛會主義建設“蚱践中即將

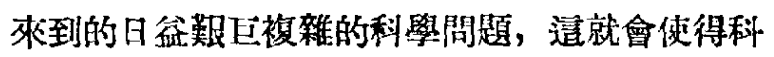
學水本得不到必要的提高, 不能適應明天的需 
要。我們必須把科學事業的發展和國家建設的筫 践統一起來, 把目前的需要和長遠的需要統一起 来。正如中國科學院的報告所指出的: “没有科學 技術的不斷支援和利學事業的相隹發展，要完成 國家的邧會主義工業化的任䅂是不可能的; 反 之，離開了皘㥛支援國家建設的科學實践，要涬 到發屡利舆事業的目的也问樣是不可能的。”我們 必须集中力量來解决今天國家建設叶的重要科學 問題，也同時第解决國家建設在明天將要砗到的

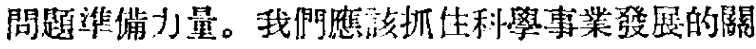
鰎性的環節, 积步地前進。在這倜涊識的基礎上，

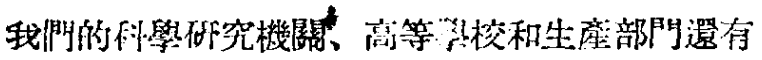

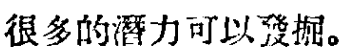

䉆了要满泛地發探科學工作的潛力, 必須把

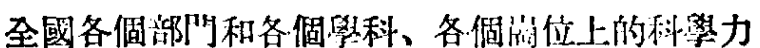
量進一步有效地組織起來, 以消除過去彼此隔閣、 工作重複和人力、設備浪損的現象。中国科學院

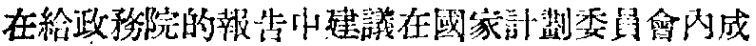

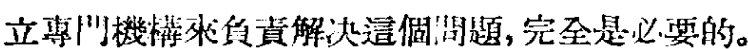
要在全國範嘼內把科學工作全面地組䋨起水，日 前我們還缺之經驗。在萑中國，科學政究工作對

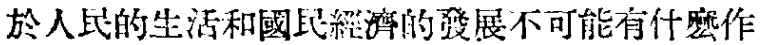
第, 各個單位和各門學科的科學家比就很少有聯 系蛽際和被此間相互聯系的需要和機會。這就造 成了今天我們很多的科學工作者缺乏整體觀念， 依然習慣於分散地孤立地工作，不關心別人的工 作，對其他有關學科與有關單位的情况了解很少， 或芼至根本不了解。今天，在國家建設的總要求 下，我們就必須樹立整體萑念念和相互協作配合的 作風, ”在有閣工作中, 應彼此經常聯系, 取得泌 切配合。只有罟樣，我們才能使科學工作對國家

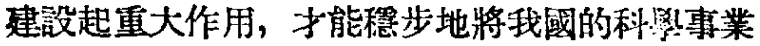
全面而有重點地發展起來。在這方面, 蘇聯科學 家学度的集體主義精神，是我們很好的學替榜樣。 蘇聯科學研究工作和生產、敎育工作三者有機聯 系的經驗，是偭得我們很好學㕷的。

要把科學力量有效地組織起來，我們科祭工 作者就必須更進一步加强團結, 拿國家的建設和

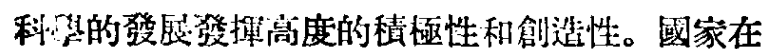
過渡時期的總路線就是全國科學工作者的進一步 国結的鞤固基礎。祖國偉大的社會主義建設將成 䉆吸引一切科學工作者的最强烈的力量。解放後
的四年中, 隨着科舆工作者思想的進步和科舉工 作任弱的日谷明確，全國科學工作者的團結是在 不斷地增强着。然而缺點和問題依然不少。例如 科學院的報告中所提到的, 在部分春年科學工作 者與老科學家之間還存在着荣些不份調的現象, 青年人往往對老科學家不够等重, 姴冰過高過 急, 這就影響了老科學家的皘㥛性, 也使得青年 人不可能很好地跟老科學家學到更多的知識和絰 驗。無疑地, 這對於科學研究工作的開展和科舉 幹部的培義都是有害的。第了改變造種情况, 我 們的青年科學工作者應济很好地领會中國其裳黨

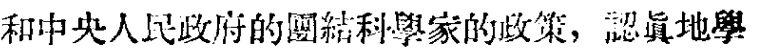

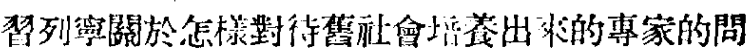
題的指示。列密敎蔀我們，要把這䦓題看成是過 渡時期的一個重要問題, 要愛護一切誠位工作、 通㬏本業並酷愛本業的科學家像愛護自己的报珠 一樣, 要懂得老科學家是叮以循着自己的途徑來 承涊共產主義思想的。我們㮣融充分佔計老科舁

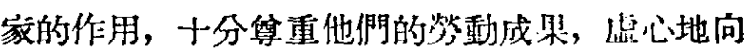

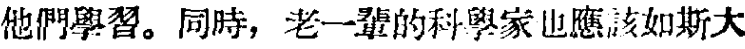
林所指示的, 要把自己的一切科學成果交給人民, 自䝠和樂意地服務於人民; 自願和架意地第青年 人打開一切科學的阿户，使他們能佔領科學的高 崒。就在老科學家之間，也應通過互相取長 㭪 短、拿重别人的勞動來加强團絬。我們要知道, 仯使熟悉科學業務的䒩科學家們在某些重要工作 上不能團結一致，它所帶來的損火將是難以估量 的。要把全國科學工作者進一步團結和組織起來, 中國科學院㗹段起很大的責任，因篇科學院是全 國科學研究中心，今後除仍嫄以主要力量來開展 院队的研究工作外，還必須密切聯系全國科學工 作者, 協助各方面的科學研究工作。全國冬個部 門和各個藏位上的科學工作者，也應主動地關心 中國科學院的工作，北同把發屡我國科學事業的

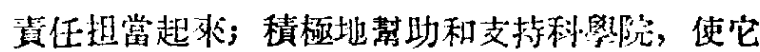
能逐步更好地具暴起领䆃全國科學工作的绦件。 這愫一個能真正團結全國科學工作者的科學中心 的建立, 對於國家建設的交援和科學事栄的發展 是十分必要的。

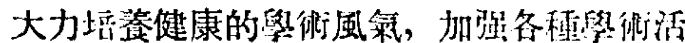
動, 也是我們迎接當前任務的一個重要方法。在 解放初的融會改草和經济恢復時期，我們科學工
- 10 -
科學通疑
1954 年. 
作者曾通過歷次的政治運動，大大提高了政治覚 悟程度，篇我國科學事業的發展打下了良好的思 想基礎。在那個時候，廣大科學工作者參加逭一 系列的㣂會活動，是完全必要的。但在國家已進 入有計劃的經湾建設時期，科學工作者的基本任 骆就應該是篇國家的建設和科學事業的發展做好 科學研究工作。各級領導機關應探取必要的措施 來保證研究業務的經常開展。䉆了能很好地推動 科學研究工作, 必須有隻備有領導地組織各種學 術性的活動。科學研究本身是一種集體的佮造性 的勞動, 也只有經常地集中了集體的智慧，交流 彼此的紃驗，對學術上不同的意見展開討論，才 能有效地解决科學工作的理論與頢踐中的重大問 題，才能不斷地提高我們的科學水平和思想水 本, 我們的團結也就更有力量。在科學研究中, 不斷地要出現和舊傳統、舊原理相矛盾的新現實 和新經驗。這種新事物和鹤思想的矛衤是永遠推 動科學前進的動力。整個科學就是在以新思想、

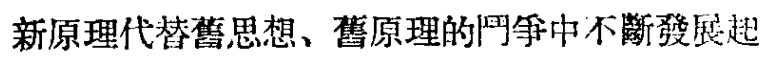
來、啙富起來的。正如斯大林所指示, 如果淡有

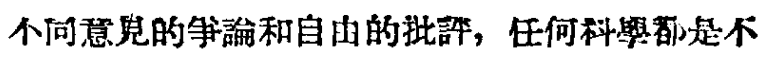
可能發展和進步的。這是一個規律。但在過去, 我們嶫這個規律是認識不足的。篇要能有效地推 動全國的科學活動，中國科學院根據蘇聯先潐絓 驗和我國目前的具體情况, 提出了關於加强科受

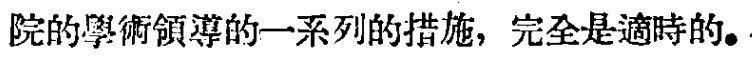
隨着這些措施的翼現，全國科學界的葍結将更加 親密起來。

多少年來篇中國科學工作者所想望的國家工 業化,一定將會循着毛主席的英明的指示, 通過 全國人民熱情的勞動，逐步地成篇現實; “中國科 學落後”也就將永遠成篇歴史的陳蹟了。在國家過 波時期總路線的光唋照耀下, 在中國共産黨和毛 主席的正確領導下，全國科學工作者，依掌自己 團結的力量, 吸取解聯先進經驗, 满滚信心地把 组國所交給我們的炎榮而繁重的歴史任務担負起 來，積極地貢缺出自己的智慧和学動，和全國人 民一近，與鹪洏堅定地问着斻會主義建設的腾利 蔃進! 